\title{
" A Proposed Strategy Based on Service Learning to Develop English Functional Writing Skills for Secondary Stage Learners" \\ "استراتيجية مقترحة قائمة على التعلم الذدمي لتطوير مهارات الكتابة الوظيفية باللغة \\ الإنجليزية لاى طلاب المرحلة الثانوية" \\ Amal Fahim ElQersh
}

A PhD Student at Curricula and Instruction Department

(EFL)

amal.elgersh@gmail.com 


\section{Abstract}

In the era of globalization, writing in English has become a necessity for the present and the future, as it is used in many aspects of our daily life: education, work, scientific research and communication. According to the World Bank Report (2003) writing in English is considered a knowledge economy skill. The National Curriculum Framework for EFL for Ministry of Education of Egypt (2012) is in line with international trends, to include proficiency in functional writing in the English language as one of the learning outcomes of secondary school students.

Out of the researcher's experience as EFL teacher for secondary stage, and through revisiting the recent local researches in the field of teaching and learning EFL writing skills (Bahgat, 2011; Elsayed, 2012; Ibraheem, 2016; Khodary , 2010; Salem, 2013; Shadi, 2015; Suleiman, 2015), and by conducting an exploratory study, the low EFL functional writing skills proficiency for secondary students was evident.

The present study investigated the effectiveness of service learning strategy in developing the EFL functional writing skills for the secondary stage students. The study adopted a quasi-experimental approach employing one group design. The participants were twenty-three students in second secondary at Mostafa Kamel Governmental Language School, Omrania zone, Giza Governorate. Data collection instruments included a preposttest of EFL functional writing skills (book review, report and letter). The experiment lasted for 10 weeks in the second term of the academic year 2017-2018.

The results showed a statistically significant difference between the mean scores of the pre- posttests in overall EFL functional writing skills in favor of the posttest results. Hence, the effectiveness of service learning was proved in developing the EFL functional writing skills of the second secondary students.

Key words: EFL Functional Writing Skills, Service Learning (SL).

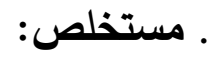

$$
\begin{aligned}
& \text { في عصــر العولمة، أصــــت الكتابة باللغة الإنجليزية ضـــرورة للحاضــر والمســتقبل، حيث يجري } \\
& \text { اسـتخدامها في العديد من جوانب حياتتا اليومية: التعليم والعمل والبحث العلمي والتواصـلـ. وفقا لتقرير البنك التك }
\end{aligned}
$$

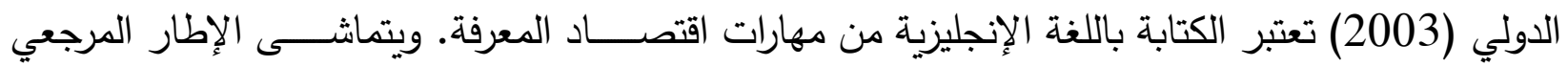

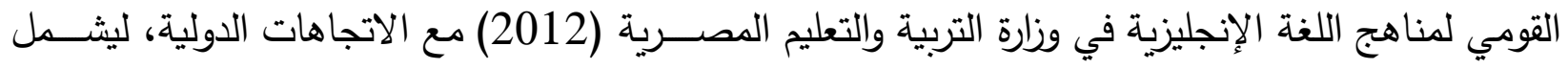

$$
\begin{aligned}
& \text { إجادة الكتابة الوظيفية باللغة الإنجليزية كأحد مخرجات التعلم لطلاب المدارس الثانوية. }
\end{aligned}
$$


من خبرة الباحث كمدرســة للغة الإنجليزية بالمرحلة الثانوية، ومن خلال مراجعة البحوث المحلية الحديثة

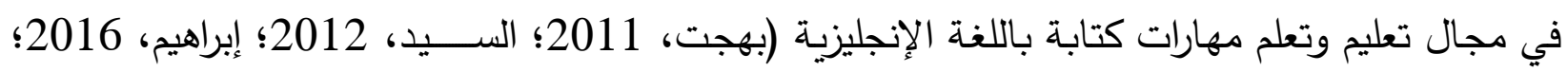

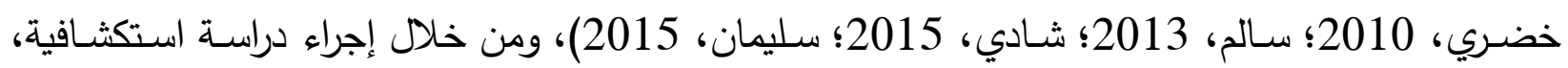

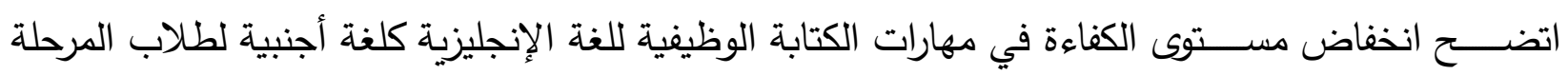

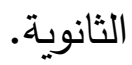

تتاولت الدراسة الحالية فاعلية استراتيجية التعلم الخدمي في تتمية مهارات الكتابة الوظيفية للغة الإنجليزية كلغة أجنبية للمرحلة الثانوية. اعتمدت الدراسة على المنهج شبه التجريبي باستخدام تصميم المجموعة الواحدة. تضمنت العينة المشاركة في الدراسة ثلاثة وعشرون طالبًا وطالبة بالصف الثاني في المرحلة الثانوية بمدرسة مصـطفى كامل الحكومية للغات بإدارة العمرانية، بمحافظة الجيزة. تضــنت أدوات جمع البيانات اختبارًا قبليًا

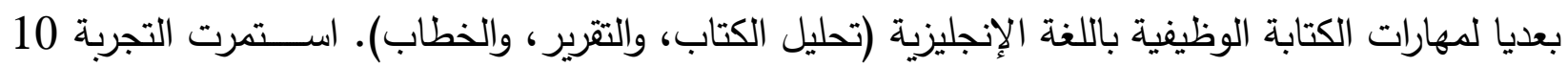
أسابيع في الفصل الثاني من العام الدراسي 2017-2018.

أشـارت النتائج إلى وجود فروق ذات دلالة إحصـائية بين متوسـط درجات الاختبارات القبلي والبعدي في

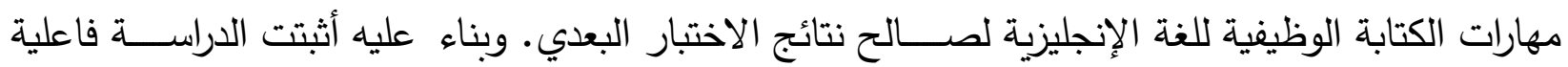

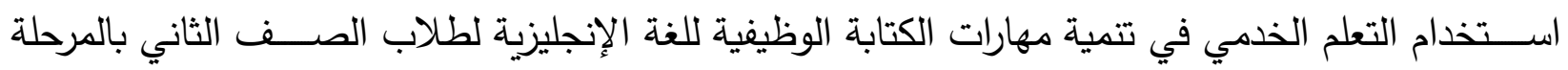
الثانوية. الكلمات المفتاحية: (الكتابة الوظيفية باللغة الإنجليزية، التعلم الخدمي). 


\section{" A Proposed Strategy Based on Service Learning to Develop English Functional Writing Skills for Secondary Stage Learners"}

\section{Introduction}

In the age of globalization, the widely used networking sites, the increasing multinational companies as well as the rapidly advanced knowledge, sciences and technologies, the need for good communication in English has become a pressing necessity internationally. The World Bank Report (2003) considered mastering English Language a compelling factor for being successful in the knowledge economy.

Accordingly, the National Curriculum Framework for English as a Foreign Language for MOE: grades 10-12 (2012) involves mastering EFL functional writing skills among the EFL learning outcomes required for secondary school students in Egypt, as EFL functional writing skills prepare secondary students for academic writing, which is the medium of written communication in most universities in Egypt. Moreover, it prepares them for pursuing their higher studies and joining the severely competitive labor market.

To fulfill the aforementioned goals, recent researches conducted locally in the field of teaching and learning EFL writing skills (Bahgat, 2011; Elsayed, 2012; Ibraheem, 2016; Khodary , 2010; Salem, 2013; Shadi, 2015; Suleiman, 2015) emphasized that more attention should be given to teaching and learning writing skills at schools. In addition, they recommended innovative and engaging teaching methodologies to be fostered for teaching the EFL writing skills in the classroom.

Scholars suggest service-learning (SL) as pedagogy to promote languagelearning of ESL students. Service learning focuses on enabling and enhancing students' learning through experience, reflection and connection to academic learning.

Service learning provides experiential learning opportunities that can create a space conducive to socialization and language acquisition, for it "emphasizes learning from firsthand, personal experiences rather than from lectures, books, and other second-hand sources" (Ravitch, 2007, p., 91). By creating reciprocal, experiential, and communicative inquiry spaces such as service learning, learners can reap the benefits from being deeply engaged .Moreover, SL brings together the realms of academia, civic learning, and personal growth to produce such "widely valued outcomes as intercultural competence and team- work" (Felten \& Clayton, 2011, p., 77). Additionally, SL encourages students to take responsibility for their 
own learning. It is also inspired by the belief that the academy has a fundamental responsibility to prepare students for lives of active citizenship (Nodoushan \& Pashapour, 2016; Stanton, Giles \& Cruz, 1999).

Apparently, service learning could be a catalyst for achieving the Egyptian MOE's vision for education: "providing a quality educational service in a nontraditional learner-centered school environment and benefiting from active learning tools and using information and communication technology (ICT) with the hope to provide the learners with self-learning and creative thinking and life skills." (Education for all 2015 National Review, p., 2).

Hence the present study is an attempt to explore the impact of implementing service learning on developing EFL functional writing skills for second year secondary school students.

\subsection{Context of the Problem}

Out of her experience as an expert EFL teacher, the researcher observed the low proficiency of EFL functional writing skills for second secondary students through tracking their scores in their monthly tests and term exams.

Additionally, by revisiting the previous studies on the EFL Functional Writing Skills locally, the researcher was informed of the lack of teaching and learning EFL Functional writing in the classroom. (Bahgat, 2011; Elsayed, 2012; Ibraheem, 2016; Khodary ,2010; Salem,2013; Shadi,2015; Suleiman,2015).and the urgency to employ innovative approaches while teaching EFL functional writing. (Abdallah, 2014; Onchera \& Manyasi, 2013; Shaath, 2015).

To further investigate the problem, the researcher interviewed 74 EFL second secondary students and 22 EFL secondary teachers from state schools and governmental language schools in the first term of the academic year 2017/2018, to explore their opinions and beliefs with regard to teaching and learning EFL Functional Writing Skills in the classroom.

The interviews with the students showed the following; the majority of the students assured the insufficiency of learning the EFL functional writing in the classroom as EFL teachers hardly allocate any time for EFL functional writing. Plus, there was a consensus among students that their exposure to functional writing in the classroom was brief and limited to writing a paragraph consisting of 100 words or writing an informal letter or email, which is mostly assigned as homework. 
EFL teachers, interviewed by the researcher, gave similar responses to the students' answers above. EFL teachers admitted the little time allocated for teaching EFL functional writing in the classroom. However, teachers put the blame on the crowded EFL curriculum, and the limited time allowed for teaching EFL lessons generally. Teachers considered the earlier reasons as obstacles to teaching EFL functional writing skills in the classroom. Besides, teachers complained about the absence of training, received from the Ministry of Education, on teaching EFL functional writing.

The researcher inferred from the previous interviews with both EFL students and teachers that there is inadequacy of teaching EFL functional writing for the secondary stage students in the classroom. Besides, there is limited exposure to EFL Functional writing forms for the secondary stage students as well, which both could be contributing factors to the deficiency of EFL functional writing skills for secondary students .

All the previous considerations necessitated conducting the present study, which suggested enhancing EFL functional writing skills for second year secondary school students through implementing a proposed strategy based on service learning.

\subsection{Questions of the Study}

The present study attempted to answer the following main question:

What is the effect of using a strategy based on service learning on developing the second secondary learners' EFL functional writing skills?

\subsection{Hypotheses of the Study}

There is a statistically significant difference between the mean scores of the study group on the EFL functional writing skills pre-posttest in favor of the posttest due to using a proposed strategy based on service learning.

Therefore, there are four sub-hypotheses derived from the main hypothesis:

1. There is a statistically significant difference between the mean scores of the study group on the overall EFL functional writing skills pre-posttest (book review, report and letter) in favor of the posttest due to using a proposed strategy based on service learning.

2. There is a statistically significant difference between the mean scores of the study group on "book review" pre-posttest in favor of the posttest due to using a proposed strategy based on service learning. 


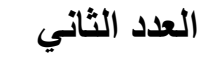

2021
المجلة الدولية للمناهج والتربية التكنولوجية

IJCTE

3. There is a statistically significant difference between the mean scores of the study group on "report" pre-posttest in favor of the posttest due to using a proposed strategy based on service learning.

4. There is a statistically significant difference between the mean scores of the study group on "letter" writing pre- posttest in favor of the posttest due to using a proposed strategy based on service learning.

\subsection{Significance of the Study}

This study is believed to benefit EFL teaching and learning field in terms of students, teachers, curriculum designers and planners and researchers.

As for students, this study may clarify the significance of teaching EFL Functional writing skills for secondary students. It could also promote their abilities to master the required EFL functional writing skills and increase their motivation towards acquiring and using EFL writing skills effectively.

With regard to teachers, the current study is hoped to draw their attention to using innovative teaching strategies based on authentic and meaningful context and student-centered learning, in EFL Functional writing skills for secondary stage students, in the hope of motivating students towards EFL learning generally, and enhancing their proficiency in EFL functional writing in specific.

This study may also favour the curriculum designers and planners when designing writing programmes, as it inspires them to create engaging lessons based on updated topics and related to people's everyday life, health ,work, environmental issues, subsequently, to create more engaged and interactive EFL classrooms, and more proficient EFL learning.

Finally, this study could also be of significant value to researchers, as it opens horizons to carry out and conduct more studies in the teaching field to investigate the effectiveness of (SL) in enhancing other language skills in secondary stage and in other educational stages.

\subsection{Delimitations of the Study}

The present study proceeded within the following delimitations:

1. This study was limited to 23 students in the second year secondary.

2. The study was implemented at Mostafa Kamel Governmental Language School in Omrania Zone, Giza Governerate.

3 . The study was carried out in the second term of the academic year 2017-2018. 
4. The study was conducted to investigate the effect of implementing SL on only three EFL functional writing skills; book review, report and letter.

\subsection{Definition of Terms}

\subsubsection{EFL functional writing skills:}

National Curriculum Framework for English as a Foreign Language for the Egyptian MOE; grades 10-12, defines functional writing skills as "The learners' ability to write for variety of audiences, purposes and in various forms to communicate meaning, ideas and emotions." (2012: 59).The various forms of EFL functional writing are further defined in The National Curriculum Framework for English as a Foreign Language for Egyptian MOE; grades 10-12, as "messages, menus, cooking recipes, letters and invitation cards, a book review, a letter to an editor, brochure, reports among others." (2012, p., 61)

Operationally, EFL functional writing skills, in the present study, means the participants' writing ability to express themselves and their ideas fluently and comprehensively, employing correct and proper organization, sense of purpose and audience, content, vocabulary, grammar and mechanics, in terms of book review, report and letter in the context of service learning.

\subsubsection{Service learning:}

Kaye (2010, p., 9) defines service learning as "a research -based teaching method where guided or classroom learning is applied through action that addresses an authentic community need in a process that allows youth initiative and provides structured time for reflection on the service experience and demonstration of acquired skills and knowledge."

Operationally, service learning (SL) is defined as a form of teaching and learning strategy based on experiential education and active learning, as it combines academic study (EFL lessons) with community service. SL includes five main stages; investigation, preparation and planning, action (community service), reflection and demonstration. Through SL, EFL learners are provided with an authentic and real-world context of language learning and language usage. Moreover, SL guarantees student-centered learning activities and environment, which could lead to creating the sense of purposeful and meaningful learning, motivation, deep engagement and finally deep understanding of the subject matter among learners, with the aim of enhancing learners' EFL functional writing skills, in terms of book review, report and letter. 


\section{Review of Literature}

\subsection{EFL Functional Writing}

When considering writing approaches, the product approach alone does not sufficiently consider the required processes of writing. The process approach does not provide learners with genre knowledge. Additionally, the genre approach undervalues the skills (or processes) needed to produce a text. Learners can have difficulty with the generation of ideas, organization and appropriateness of language when writing. Learners should therefore be offered the opportunity to develop their writing skills through the functional approach ( real life activities) which enable the learner to identify the purpose of writing (field) and accordingly; the appropriate genre of writing (mode); the relationship between the writer and the reader(tenor).

Therefore, a functional approach to language in general and writing in particular achieves communication within writing, and ensures meaningful use (Hartnett, 1997). Writing thus becomes an effective means of communication with others, not merely a means of displaying academic knowledge. Further, writing is strongly enhanced when instruction is explicitly designed to address learners' specific needs and objectives; it becomes a main device for self-expression, shaping ideas, and convincing others (Graham \& Perin, 2007; Salem, 2013).

In the same vein, Onchera and Manyasi (2013, p., 842) clarify that functional Writing skills are important to learners who need them in their everyday communications in school and even after school and individuals of whatever age who possess these skills are able to participate and progress in education, training and employment as well as develop and secure the broader range of aptitudes, attitudes and behaviors that enable them to make a positive contribution to the school, community in which they live in and places of work.

Moreover, Shaath (2015) \& Abdallah (2014) consider the functional writing as a reflection of the present and future life where rapid technology progress in everything around. Abdallah (2014) proceeds that functional writing's importance emerges from people's needs which become more complicated and their lives become faster, so a person has to be accurate and fast in writing to perform his/her work and aim. Further; Abdullah (2014) clarifies EFL functional writing fields' plurality and variety embody most situations needed by a person in his/her life (messages, notes, emails, letters, etc.), work (job application, records, letters, emails, etc.) and learning (notes, essays, science reports, etc.). Shaath (2015) elaborates that people who progress in their careers, their ability to write clearly and accurately 
becomes more important. In other words, as people get higher position of responsibility, the demand for writing will increase. This means that developing learners' functional writing skills is not just about here and now; it is about preparing them for the challenges they will face in the future.

\subsection{Service Learning (SL)}

Brian (2016), The Office of Community Engagement at California State University, Northridge (CSUN, 2017), Kaye (2010) all differentiate service learning from other forms of community service or volunteer work because education is always at its core; students actively participate in the process of understanding, integrating, and applying knowledge from various subject areas to improve their communities, as shown in figure 1.

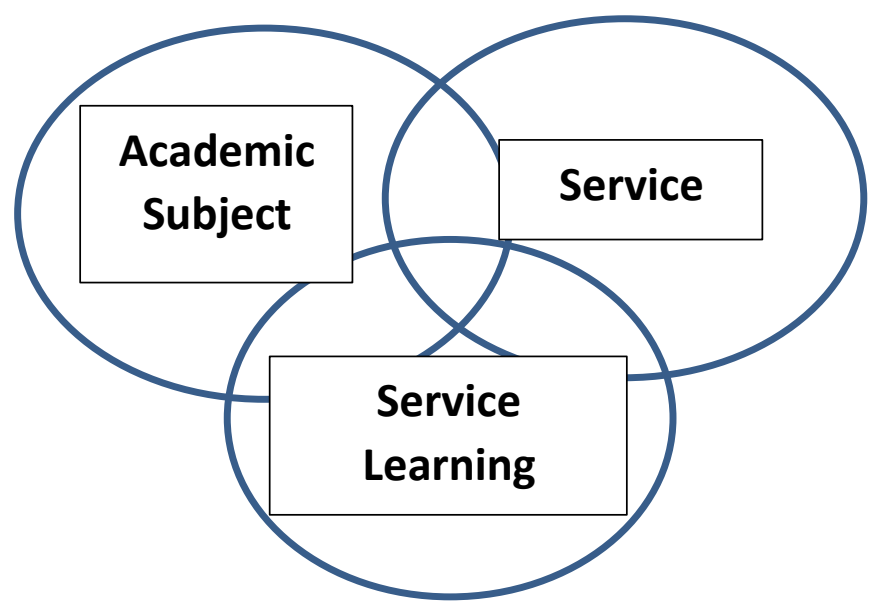

Figure 1. Service Learning= Academic Subject + Service

(Source: Kaye, 2010:48)

Though coining the term "service-learning" occurred in 1967(Giles \& Eyler, 1994), Service-learning has philosophical roots in the experiential learning theories which dates back to Dewey's vision on education (1938), in which the functional role of learning through experience is highlighted, as well as the required criteria to ensure that experience and learning are connected and continuous. Dewey considers education a six-step process of:

- encountering a problem

- formulating the problem as a question to be answered

- gathering information to answer the posed question 
- developing a hypothesis

- testing the hypothesis

- making warranted assertions

Moreover, Dale's (1969) focus on actionable learning suggests that learning outcomes and knowledge retention are related to the ways in which knowledge is transferred to learners: the more experiential the learning, the higher the level of knowledge retention.

Current learning and brain research supports and explains earlier theories of experiential education. Zull (2002) shows that the brain is responsible for four basic functions: getting information (sensory cortex,) making meaning of information (back integrative cortex,) creating new ideas from these meanings, (front integrative cortex,) and acting on those ideas (motor cortex.) These regions approximately align with Kolb's Learning Cycle into four pillars of human learning: gathering, analyzing, creating, and acting. By engaging students in high quality service-learning, we require them to use each of the four regions of their brains thereby evoking emotion and connecting content. See figure 2.

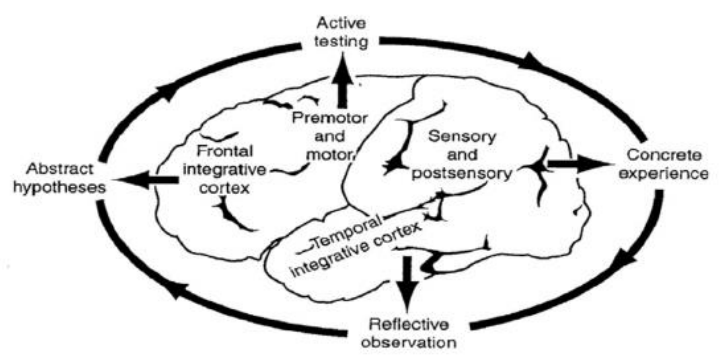

Figure 2. The Experiential Learning Cycle and regions of cerebral cortex (Source: Zull, 2oo2:15)

SL is a form of experiential learning which facilitates a deep approach to learning. Deep learning transform 'factual knowledge into usable knowledge' (Bransford, Brown, \& Cocking, 2000,p., 16) which requires critical thinking skills, integration of knowledge over time and subjects, a theoretical application of knowledge to practical situations and higher order skills of analysis and synthesis. When students have opportunities to actively use classroom knowledge, they develop an understanding of when and how knowledge can be applied in different contexts. 
Kaye (2010, p; 14) states: "Service learning enables students to take initiative, make decisions, interact with community representatives, develop critical thinking skills, put their ideas into action, assess and evaluate what happened". Ultimately, these abilities, when strengthened by repeated service learning, amount to youth leadership.

Moreover, Service learning incorporates multiple ongoing reflection activities that prompt the participants' deep thinking and analysis about community problems and alternative solutions. Moreover, such reflection activities encourage participants to examine their preconceptions and assumptions in order to understand their roles and responsibilities as citizens (Bringle \& Hatcher, 1996; Daudlin,1996; Kaye,2010).

\subsubsection{Types of service learning}

Service Learning can take many forms. Kaye (2010) and CSUN (2017) categorize service-learning projects as follows:

\section{- Direct service:}

Through direct service students interact person- to- person and face- to- face, and affect directly the recipients, such as tutoring younger children or working with refugees. Students participating in direct service learn about caring for others and develop problem-solving skills.

- Indirect service:

With indirect service students do not see the recipients; however, their actions benefit the community or environment as a whole. Examples include donating picture books for a preschool literacy program, or collecting clothes for the needy. Students engaged in indirect service learn about cooperation, teamwork, organizing and prioritizing. They also gain knowledge related to academic content and apply through action.

- Advocacy:

The intent of advocacy is to raise awareness or to promote action on an issue of public interest. Through advocacy students speak for the unvoiced. Related activities include writing letters, performing a play, or giving a public speaking. Student advocates learn about perseverance, understanding rules systems and processes. They also experience civic engagement and deal with adults.

- Research: 


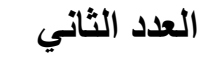

2021
المجلة الاولية للمناهج والتربية التكنولوجية

IJCTE

Research activities include finding, gathering and reporting on information, through conducting experiments, surveys or interviews. Through research students gain enhanced skills in organization, assessment, and evaluation.

\subsubsection{Phases of service learning}

CSUN (2017) suggests that effective service-learning practice involves four activities: preparing and designing a service learning experience, implementing a service experience, learning through reflection, and assessing student learning and service activity.

Meanwhile, Kaye (2010, pp., 16-17) assures that successful service-learning is a process that includes five stages:

\section{Investigation:}

All service learning begins with investigation: 1. Investigation within the student population, called "Personal Inventory" through which students recognize their abilities and talents. 2. Investigation of the community need, through designing a survey, conducting interviews, using varied media such as books and the internet, and drawing from personal experience and observation. Community partners are identified at this stage as well.

\section{Preparation and planning:}

Having recognized their personal inventory and the community need, students need at this point to plan for action, through finding more on the underlying problem and examining the possible resources both primary and secondary. Students may also establish partnerships with other teachers, classrooms, local agencies, colleges, or organizations that offer resources.

\section{Action:}

Solid preparation enables students to confidently carry out their plan for action and apply what they learned on classroom lessons, in a safe environment that offers them vast opportunities to develop their knowledge, skills and talents and helps them to create the sense of social responsibility and care for others. Moreover, it helps students to put their values, skills, talents and knowledge on test and figure out the results by themselves. The duration of the plan varies as it can take an academic year, a semester, two weeks, or a single day.

\section{Reflection:}

Reflection is the glue that holds service and learning together to provide optimal educative experience (Eyler, Giles, \& Schmiede, 1996). Reflection is a vital and ongoing process as it occurs before, during and after implementation. It is a pause 
button that gives students the time to explore the impact of what they are learning. Therefore; it integrates learning and experience with personal growth and awareness. Community can also provide their feedback and reflection. Reflection can include assessment tools like oral reflection, small group discussion, presentations, surveys, reflective journals, essays, exams, reports, and research projects.

\section{Demonstration:}

The fifth stage of service-learning is demonstration, as Kaye $(2010$, p., 18) calls it "The Big Wow!" and she proceeds "it is a significant achievement for students to demonstrate what they've learned clearly and publicly." Demonstration can be accompanied by celebration as a sign of recognition for students on their contribution to their community.

\section{Previous studies}

\subsection{Related studies to EFL functional writing}

The researcher surveyed some recent studies that had dealt with EFL functional writing skills both locally and internationally. In this regard, Khodary (2010) conducted a study that aimed at developing some functional writing skills (email, memo, fax, curriculum vitae, application letter and report) of studentteachers of English at Women's college - Ain Shams University; implementing a proposed program based on the Process Writing Approach. Findings of the study showed that the process writing approach was effective in developing some functional writing skills of student-teachers of English Language.

In the same vein, Bahgat (2011) carried out a study aiming at developing EFL functional writing skills (letter, email, paragraph) of $3^{\text {rd }}$ preparatory stage students in Menoufya governmental schools. The researcher adopted a strategy based on Mastery Learning Model for developing the participants' functional writing skills. The results revealed the effectiveness of the proposed strategy in developing the EFL functional Writing Skills of $3^{\text {rd }}$ year preparatory stage.

Also, Salem (2013) performed a study aiming at investigating the effect of using a program based on the writing workshop approach on developing functional writing skills of pre-service teachers of English in Hurgada faculty of Education. Findings of the study indicated that the writing workshop program had significant effect on improving the participants' functional writing. It was recommended that peer and group work into writing should replace an individual activity. 
More closely, Onchera and Manyasi (2013) conducted a descriptive study, in six secondary schools in Nyanza Province (Kenya), to investigate to what depth learners are exposed to appropriate functional text varieties; identify the kind of support teachers give learners in their functional writing tasks and establish how this exposure influences the teacher in teaching functional writing for effective communication. 720 students and 18 teachers of English language participated. The results showed that teachers have different understanding about the teaching of functional writing skills. Hence; there were differences in their practices, approaches and the depth to which learners are exposed to appropriate functional writing text varieties; that students are not fully exposed to varieties of functional writing texts; that teachers give minimal support to learners. Lastly, minimum effort is employed by the teachers to show the learners how functional writing should be seen as a means of effective communication.

Additionally, Shaath (2015) performed a study aimed at investigating the effect of a suggested program based on Self-Regulated strategy development model on developing students' overall functional writing skill in identified writing fields(writing letter-email, report, memo, article and summary) and on promoting their attitudes towards functional writing. An experimental group consisted of thirty students at the faculty of Economics and Administrative Science, AlAzhar University in Gaza, were the participants of the study. Results revealed large effect size of the suggested program on developing students' overall functional writing skills and promoting their attitudes towards EFL functional writing skills

\subsection{Related Studies to service learning}

The present study was informed by the review of previous related studies on service learning that some previous studies focused on the effect of service learning on English language learners' skills. For example, ElWell \& Bean (2000) facilitated a community service-learning project for ESL students in a reading class at the community college to examine how ESL students benefitted from participating in service-learning project. The project took place in Foothill College, located in Los Altos Hills, California. The participants were 28 students (18 females and 10 males). The students had come to the U.S. from different countries around the world. Near the end of the quarter, the students were asked to complete a nine- item questionnaire related to the community service-learning project and the reading class assignment. The results of this service-learning project showed that SL was highly beneficial on several levels: academic, personal, and societal. 
Moreover, Miller, Berkey, Griffin, (2015) carried out a study to explore how service-learning impacts the development and transition of pathway program students at Northeastern University (USA). The Researchers used qualitative research methods. Results of the study indicated that service-learning contribute to pathway program students' sense of agency, including organization, time management, initiative, self-advocacy, and self-confidence and their Englishlanguage speaking skills and enhance cross- cultural collaborations with peers in their degree programs. Moreover; service-learning enhance the students' English language proficiency needed for success in their degree programs.

In addition, Riley \& Douglas (2016) conducted a study to explore the impact of the service-learning experience from the perspective of the participants through The Multicultural Café, a food service-learning platform for adult learners of English as an Additional Language (EAL), learners operated over a 7-month period at a regional college in the British Columbia interior in Canada. The participants represented six different first languages. The researcher used a qualitative case study research design, through a questionnaire, semi-structured interviews, and a focus group. Data were gathered from participants $(n=10)$. Findings of the study showed opportunities for authentic interactions with customers and with other volunteer coworkers emerged as two of the primary outcomes of the service learning experience. Moreover, incorporating the service learning into the participants' English language learning experiences appeared to enhance their interactions within the college community.

Meanwhile, some other previous studies focused on the effectiveness of the overall learning outcomes of adult learners when using service learning. For example, (Brail, 2016) conducted a study aimed at evaluating whether students who participate voluntarily in a service-learning activity achieve higher learning outcomes measured by grades, than students who voluntarily choose not to participate in service learning at a large North American research university, University of Toronto. The results came from analyzing 338 students records. Findings indicated that, overall, students achieved higher grades as a result of participation in service learning. Similarly, (Boss, 1994; Eyler and Giles, 1999; Astin\& et al, 2000) conducted studies that proved SL improved students' academic performance, cognitive and moral development.

Some other studies focused on the effectiveness of SL in increasing students' sense of civic and social responsibilities, such as plann (2002), and Katawy \& Abou Jamous (2015). The latter conducted a study aimed at investigating the impact of using service learning in developing the citizenship of the tenth grade students in 
Jordan. Findings of both studies showed that students' concepts of citizenship increased as a result of participating in service-learning projects.

\subsection{Commentary on previous studies}

Through the review on literature and the related studies to EFL functional writing, the researcher was informed of: the importance of exposing students to different fields of EFL Functional Writing with different purposes. Plus, EFL functional Writing should be taught as a means of communication, and hence it should be taught through authentic and meaningful context. Moreover, it is necessary to vary the practices and teaching approaches while teaching EFL functional Writing and communicative approaches are among the most effective strategies in teaching EFL Functional Writing.

However, the researcher was informed of the lack in research on functional writing in the fields of letter, report and review writing for the secondary stage students. Also, the researcher realized the lack in using strategies that provide students with authentic and meaningful context in the previous studies. Therefore, the present study attempted to fill in such gaps in the literature of teaching and learning EFL functional writing skills for secondary students.

In regard with reviewing the literature and previous studies related to Service Learning, they were beneficial to the present study. They enabled the researcher to better understand the features of SL, its importance, types, and phases. Hence, they enabled the researcher to implement SL in developing second secondary students' EFL functional writing skills.

However, throughout the review on service-learning literature and related studies, the researcher was informed that the previous studies that aimed to investigate the effectiveness of using SL in enhancing English Language were only carried out on improving ESL for English language learners in USA and Canada, whereas there was little attention given to service learning in Egypt and the Arab world. Even such little research, conducted in Egypt and the Arab world, only focused on using SL in National and Civic Education subjects. Besides, (to the best of the researcher's knowledge), there was lack in quantitative research conducted for applying SL in general, as most of the previous research that applied SL, used qualitative methods. Furthermore, there was very little research using SL at the secondary stage, as most of the previous studies that implemented SL were conducted at universities.

\section{Methodology}




\subsection{Design of the Study}

The present study is a quasi-experimental one, which adopted one group study. The researcher administered the pre-posttest to the study group before and after the experiment to investigate the effectiveness of SL on developing EFL functional writing skills for the second secondary students.

\subsection{Participants}

Participants of the present study consisted of one intact class of the researcher; 23 students aged between 16-17 years old, in second secondary year, at Mostafa Kamel Governmental Language School, Osmania Zone, Giza Governorate. Participants were assigned to one study group. It is also worth mentioning that the participants, as language school students, were doing two English Language courses; an ordinary level English Language course as well as an advanced English Language level course for upper intermediate learners in accordance with Common European Framework of Reference for Languages (CEFR).

\subsection{Instruments}

\subsubsection{An EFL functional writing skills pre-posttest}

The pre-posttest consisted of 3 parts. Part one included two questions on book review. Part two had two questions on report writing. Finally, part three included two questions on letter writing. The examinee had to choose one question from each part to answer. Each part was scored out of 15 points. The time allocated for each part was 30 minutes. The total points of the total pre-posttest were 45 points. And the total time allocated for the three parts of the pre-posttest was 90 minutes.

\subsubsection{Test validity}

To ensure the validity of the test a preliminary version of the pre-posttest was submitted to the jury members to evaluate the questions in terms of their appropriateness to second secondary students' level and the targeted functional writing skills required by second secondary students. The jury suggested some modifications, for example they suggested replacing the preliminary required range of words (250), (suggested by the researcher in the preliminary version of the preposttest) with (120) words (in the final version of the pre-posttest), to conform with the Common European Framework of Reference for Languages (CEFR), and EFL curriculum of second secondary in Egypt. Accordingly, the required modifications were made in the final version of the pre-posttest.

\subsubsection{Test reliability}




\section{A. Test-Retest Reliability}

The pre-posttest was piloted to determine test-retest reliability. The pilot test was conducted twice with 20 students in second secondary, who did not participate in the study. The time between the two administrations was two weeks. The scores of the pre-posttest administrations were correlated using Pearson's Coefficient of correlation. The correlation coefficient was 0.982 , which was significant at 0.01 level.

\section{B. Inter- Rater Reliability}

In the present study, three raters including the researcher scored the participants' answers to the pre-posttest; accordingly, inter-rater reliability was calculated using Cronbach's Reliability Scale. Cronbach's Alpha was 0.93, indicating a very high internal consistency since the reliability coefficient was $>0.70$.

\subsubsection{Timing of the test}

The duration of the test was determined by calculating the average of the summation of time spent on answering the pre-posttest by the 20 students (in the pilot study). Accordingly; the time allocated for each part of the pre-posttest was 30 minutes. Then the time allocated for the total pre-posttest was 90 minutes.

\subsection{Service-Learning Strategy}

\subsubsection{Phases}

The researcher followed Kaye's (2010) five stages in implementing service learning in the present study:

\section{Investigation}

2. Preparation and planning

3. Action

4. Reflection

5. Demonstration

\subsubsection{Duration of the Experimentation}

The experiment began in the second term of the academic year 2017-2018. It lasted for 10 weeks to complete 3 service-learning projects. Each project lasted for 10 
sessions, 3 sessions a week, 45 minutes a session. The researcher took advantage of the 2 weekly activity classes (assigned in the school timetable), plus, one after school session to implement the experiment of employing service learning.

\subsubsection{Teacher's role}

Throughout using SL, the teacher's role is shifted from the traditional form of "transmission" teaching and from being a dominant information feeder to fill the varied roles of coach, facilitator, and co-learner. Moreover, it creates an active and engaging teaching and learning environment that enhances the quality of the learning outcomes, like Learning that occurs in a meaningful context, encouraging teamwork among students, paying attention to individual differences in learning. In addition, teachers adapt their instruction as accordingly to the developmental levels of the students. Therefore, SL guarantees progressing from teacher-centered teaching to student-centered learning.

Such shifting role of teachers is described as movement from "sage on the stage", to "the guide on the side" and moving finally to "the meddler in the middle". The teacher becomes more of experimenter and risk-taker alongside the students, who are involved much more in co-production of the learning processes that take place.

\subsubsection{Students' role}

The shift in the teacher's role through using SL is reflected upon the students' role which shifted from a passive role to an active role in the learning process, and from individualistic approach of learning to cooperative approach of learning. Therefore, students' role in SL can lead to potential learning outcomes of (I) working with others, (ii) critical enquiry and reflection, (iii) acquiring skills, (iv) communication and articulation of knowledge, (v) managing learning and how to learn, (vi) self and peer assessment, and (vii) self-directed learning.

\subsubsection{Assessment}

\section{Formative assessment}


The formative assessment took place before, during and after the processes of SL to facilitate, scaffold and therefore to enhance students' learning. The formative assessment took place in the form of workshops, oral presentations, posters, acting sketches, producing documentaries, reflection journals by the students and followup sessions conducted by the teacher to facilitate and enhance students' learning.

\section{Summative assessment}

The summative assessment took place in the form of the pre-posttest to explore the effect of SL on improving second secondary students' functional writing skills and therefore to assess students' learning.

\subsubsection{Implementation of Service-Learning Strategy}

It is recommended that Teacher should conduct an orientation session for introducing service learning to the students prior to using it, with the students in the class, for the first time. In such a session Teacher should present the definition of service learning, its importance. In addition, Teacher should demonstrate some examples of previous service-learning projects.

Project 2 is to be followed as an example of implementing Service Learning in the present study:

\section{Service Learning project 2}

Project Title: Water is life

Grade Level: Second Secondary

Curriculum connections: Unit 12: Population, health \& the Environment \& Unit 3 Water \& Food safety

Type: Advocacy

Duration: 3 weeks

\section{Learning objectives:}

- Students do research on environmental issues like water pollution and water shortage in Egypt.

- Students do a field trip to Soil \& Water \& Environment Research Institute (SWERI) to learn more on the environmental issue of water shortage in Egypt. 
- Students identify environmental problems, for example water shortage and water pollution.

- Students work collaboratively to raise awareness among their school friends on water shortage in Egypt through producing a documentary; conducting forums; designing posters and setting competitions.

- Students write a report on water shortage in Egypt.

\section{Stage 1 Investigation: (3 sessions a week)}

1. Teacher invites students to do research on the topic "environmental issues; water shortage and pollution in Egypt". Teacher encourages students to design an interview to survey the needs of the community regarding the topic.

2. Students survey the needs of the community concerning the topic "environmental issues; water shortage and pollution in Egypt" throughout an interview to gather evidence on community need regarding the issue.

3. Students present the results of the interview and identify the targeted community \& Teacher brainstorms students' ideas on the needed service for the targeted community. Then students come to a consensus on the necessity to:

Create awareness among primary, preparatory and secondary school students on the issue of "water shortage in Egypt, The problem and solution" through:

- Producing a documentary.

- Holding forums.

- Designing posters.

- Conducting competitions.

\section{Formative assessment:}

Teacher assesses students' investigation for the community service through a discussion session, students' interview results, students' pre-reflection (Reflection Journal), photo documentation.

\section{Stage 2 Planning and Preparation (3 sessions a week)}

Students identify the community service \& make an action plan that includes the participants from the service learning team (who), the tasks they are going to do (what), and the duration for the preparation (when) and the resources needed as shown in table 1: 


\section{Table 1}

Plan for the preparation of Service Learning Project 2 by participants

\begin{tabular}{|l|l|l|l|}
\hline Who & Will do what & By when & $\begin{array}{l}\text { Resources } \\
\text { needed }\end{array}$ \\
\hline & $\begin{array}{l}\text { Preparing for the } \\
\text { field trip to SWERI } \\
\text { the documentary } \\
\text { Writing a script for } \\
\text { thehool }\end{array}$ & $\begin{array}{l}\text { Information } \\
\text { gathered from the } \\
\text { research findings } \\
\text { \& lecture by Dr } \\
\text { Fouad Ahmed } \\
\text { during field trip } \\
\text { to SWERI }\end{array}$ \\
\hline & $\begin{array}{l}\text { Recording the script } \\
\text { Making the } \\
\text { documentary }\end{array}$ & $\begin{array}{l}\text { Composing questions } \\
\text { for the competition }\end{array}$ & Mobile recorder \\
\hline & Designing posters & $\begin{array}{l}\text { IT skills } \\
\text { Information } \\
\text { documentary }\end{array}$ \\
\hline & & $\begin{array}{l}\text { Money donation } \\
\text { from participants }\end{array}$ \\
\hline
\end{tabular}

\section{Formative assessment}

Teacher assesses students' planning and preparations through observation, follow up sessions, photo documentation and during reflection journal.

\section{Stage 3 Taking Action: Implementation of action Plan (3 sessions)}

Students are divided into three groups to implement the plan for action that includes the participants, the service, the duration of the service and the resources needed as follows in table 2:

Table 2 


\section{Implementation of action plan by participants}

\begin{tabular}{|l|l|l|l|}
\hline Who & Will do what & By when & $\begin{array}{l}\text { Resources } \\
\text { needed }\end{array}$ \\
\hline & $\begin{array}{l}\text { Making } \\
\text { arrangements for } \\
\text { scheduling the } \\
\text { forums }\end{array}$ & $\begin{array}{l}\text { Teachers in } \\
\text { charge of the } \\
\text { multimedia lab \& } \\
\text { the schedule of } \\
\text { the lab }\end{array}$ \\
\hline & $\begin{array}{l}\text { Holding the } \\
\text { forums \& } \\
\text { competitions }\end{array}$ & $\begin{array}{l}\text { Data show \& } \\
\text { computer in } \\
\text { Multimedia lab }\end{array}$ \\
\hline & Taking photos & camera \\
\hline & Putting up posters & & Glue \\
\hline
\end{tabular}

\section{Formative assessment:}

Teacher assesses students' action or project through observation, students' post reflection (Reflection Journal), photo documentation, feedback by the targeted community, follow up sessions.

\section{Stage 4 Reflection (one session)}

\section{Formative assessment:}

Teacher administers the posttest on report writing for the participants (service learning team).

\section{Stage 5 Demonstration and celebration}

Students can share their projects of service learning in a culminating event through different ways; oral presentations, photo and film documentation and community feedback.

\section{Results}

In order to test the study hypotheses, the statistical package of social science (SPSS), version 22.0, was used to calculate the mean scores and standard deviations of the 
study group in the pre and posttests. The degree of freedom; " $t$ " value and level of significance were also calculated to determine the correlation between the dependent variable (EFL Functional Writing skills) and the independent variable (Service Learning) of the study. The Eta Squared $\eta^{2}$ formula was calculated as well to determine the effect size of the independent variable of the study (Service Learning) on the dependent variable (EFL functional writing skills).

First hypothesis

There is a statistically significant difference between the mean scores of the study group on the overall EFL functional writing skills pre-posttests (book Review, report and letter) in favor of the posttest due to using a proposed strategy based on service learning.

To test the first hypothesis, the researcher used the T-Test. The obtained results are shown in table (3).

Table 3

Results of T-Test of the Pre and Post Assessments of Overall EFL Functional Writing Skills

Writing

Skills

$\begin{array}{cccccccc}\text { Test } & \text { N } & \text { Mean } & \begin{array}{c}\text { Std. } \\ \text { Deviation }\end{array} & \begin{array}{c}\text { "t" } \\ \text { Value }\end{array} & \text { df. } & \text { Sig. } & \eta^{2} \\ \text { pre } & 23 & 22.78 & 5.13 & 5.05 & 22 & .000 & .54 \\ \text { Post } & 23 & 31.39 & 6.37 & & & & \end{array}$

Table (3) shows that there is statistically significant difference between the mean scores of study group on "overall EFL functional writing skills" pre and posttests in favour of the posttest. Table (3) also shows that the calculated " $t$ " value of study group, on "overall EFL functional Writing Skills" Test, was (5.05) at (.000) level of significance and (22) degree of freedom. Consequently, the null hypothesis was rejected, and it was inferred that there was a correlation between the dependent variable (EFL functional writing skills) and independent variable (service learning). Table (3) as well shows that Eta Squared 12 formula of "overall EFL functional writing skills" Test was (.54). In such case, the effect size of the independent variable on the dependent variable was large.

\section{Second hypothesis}

There is a statistically significant difference between the mean scores of the study group on "book review" pre-posttests in favor of the posttest due to using a proposed strategy based on Service Learning. 
To test the second hypothesis, the researcher used the T-Test. The obtained results are shown in table (4).

Table 4

Results of T-Test of the Pre and Post Assessments of "Book Review" Writing

\begin{tabular}{ccccccccc}
\hline Sub-Skills & Test & N & Mean & $\begin{array}{c}\text { Std. } \\
\text { Deviation }\end{array}$ & $\begin{array}{c}\text { "t" } \\
\text { Value }\end{array}$ & df. & Sig. & $\eta^{2}$ \\
\hline Style & Pre & 23 & 1.3 & $\mathbf{0 . 4 7}$ & 5.97 & 22 & .000 & .62 \\
& Post & 23 & 2.1 & 0.42 & & & & \\
Content & Pre & 23 & 1.3 & 0.45 & 6.58 & 22 & .000 & .66 \\
& Post & 23 & 2.2 & 0.49 & & & & \\
Organization & Pre & 23 & 1.4 & $\mathbf{0 . 5 0}$ & 6.25 & 22 & .000 & .64 \\
& Post & 23 & 2.4 & 0.58 & & & & \\
Vocabulary & Pre & 23 & 1.7 & $\mathbf{0 . 5 6}$ & 2.68 & 22 & .010 & .25 \\
& Post & 23 & 2.2 & $\mathbf{0 . 6 5}$ & & & & \\
Grammar \& & Pre & 23 & 1.5 & $\mathbf{0 . 5 9}$ & 2.55 & 22 & .014 & .23 \\
Mechanics & Post & 23 & 2.0 & $\mathbf{0 . 6 7}$ & & & & \\
Total & Pre & 23 & 7.2 & 2.1 & 5.50 & 22 & .000 & .58 \\
& Post & 23 & 10.8 & 2.4 & & & & \\
\hline
\end{tabular}

Table (4) shows that there is statistically significant difference between the mean scores of experimental groups on "book review" pre and posttests in favor of the posttest. Table (4) also shows that the calculated " $t$ " value of study group, on "book review" test, was (5.50) at (.000) level of significance and (22) degree of freedom. Consequently, the null hypothesis was rejected, and it was inferred that there was a correlation between the dependent variable (EFL functional writing skills) and independent variable (service learning). Table (4) as well shows that Eta Squared $\rceil 2$ formula of "book review" test was (.58). In such case, the effect size of the independent variable on the dependent variable was large.

\section{Third Hypothesis}

There is a statistically significant difference between the mean scores of the study group on "report" pre-posttests in favor of the posttest due to using a proposed strategy based on Service Learning.

To test the third hypothesis, the researcher used the T-Test. The obtained results are shown in table (5). 
Table 5

Results of T-Test of the Pre and Post Assessments of "Report" Writing

\begin{tabular}{ccccccccc}
\hline Sub-Skills & Test & $\mathrm{N}$ & Mean & $\begin{array}{c}\text { Std. } \\
\text { Deviation }\end{array}$ & $\begin{array}{c}\text { "t" } \\
\text { Value }\end{array}$ & df. & Sig. & $\eta^{2}$ \\
\hline Style & Pre & 23 & 1.4 & 0.51 & 2.72 & 22 & .009 & .25 \\
& Post & 23 & 2.0 & 0.77 & & & & \\
Content & Pre & 23 & 1.6 & 0.51 & 3.81 & 22 & .000 & .40 \\
& Post & 23 & 2.1 & 0.42 & & & & \\
Organization & Pre & 23 & 1.7 & 0.69 & 3.04 & 22 & .004 & .30 \\
& Post & 23 & 2.3 & 0.44 & & & & \\
Vocabulary & Pre & 23 & 1.6 & 0.50 & 2.86 & 22 & .006 & .27 \\
& Post & 23 & 2.0 & 0.43 & & & & \\
Grammar \& & Pre & 23 & 1.3 & 0.47 & 2.76 & 22 & .008 & .26 \\
Mechanics & Post & 23 & 1.9 & 0.95 & & & & \\
\multicolumn{1}{c}{ Total } & Pre & 23 & 7.7 & 2.19 & 3.90 & 22 & .000 & .41 \\
& Post & 23 & 10.2 & 2.28 & & & & \\
\hline
\end{tabular}

Table (5) shows that there is statistically significant difference between the mean scores of study group on "report" pre and posttests in favor of the posttest. Table (5) also shows that the calculated " $t$ " value of experimental group, on "report" test, was (3.90) at (.000) level of significance and (22) degree of freedom. Consequently, the null hypothesis was rejected, and it was inferred that there was a correlation between the dependent variable (EFL functional writing skills) and independent variable (service learning). Table (5) as well shows that Eta Squared $\prod 2$ formula of "report" test was (.41). In such case, the effect size of the independent variable on the dependent variable was large.

\section{Fourth hypothesis}

There is a statistically significant difference between the mean scores of the study group on "Letter" pre- posttests in favor of the posttest due to using a proposed strategy based on Service Learning. 
To test the fourth hypothesis, the researcher used the T-Test. The obtained results are shown in table (6).

\section{Table 6}

Results of T-Test of the Pre and Post Assessments of "Letter" Writing

\begin{tabular}{ccccccccc}
\hline Sub-Skills & Test & $\mathrm{N}$ & Mean & $\begin{array}{c}\text { Std. } \\
\text { Deviation }\end{array}$ & $\begin{array}{c}\text { "t"” } \\
\text { Value }\end{array}$ & df. & Sig. & $\eta^{2}$ \\
\hline Style & Pre & 23 & 1.5 & 0.51 & 2.55 & 22 & .014 & .23 \\
& Post & 23 & 2.0 & 0.64 & & & & \\
Content & Pre & 23 & 1.7 & 0.47 & 2.66 & 22 & .011 & .24 \\
& Post & 23 & 2.1 & 0.63 & & & & \\
Organization & Pre & 23 & 1.6 & 0.58 & 3.28 & 22 & .002 & .33 \\
& Post & 23 & 2.2 & 0.67 & & & & \\
Vocabulary & Pre & 23 & 1.7 & 0.48 & 2.89 & 22 & .006 & .28 \\
& Post & 23 & 2.1 & 0.63 & & & & \\
Grammar \& & Pre & 23 & 1.5 & 0.51 & 2.21 & 22 & .032 & .18 \\
Mechanics & Post & 23 & 1.9 & 0.79 & & & & \\
\multicolumn{1}{c}{ Total } & Pre & 23 & 8.0 & 2.0 & 3.24 & 22 & .002 & .32 \\
& post & 23 & 10.3 & 2.9 & & & & \\
\hline
\end{tabular}

Table (6) shows that there is statistically significant difference between the mean scores of study group on "Letter" pre and posttests in favor of the posttest. Table (6) also shows that the calculated " $t$ " value of experimental group, on "letter" test, was (3.24) at (.002) level of significance and (22) degree of freedom. Consequently, the null hypothesis was rejected, and it was inferred that there was a correlation between the dependent variable (EFL functional writing skills) and independent variable (Service Learning). Table (6) as well shows that Eta Squared $\eta 2$ formula of "report" test was (.32). In such case, the effect size of the independent variable on the dependent variable was large.

\section{Discussion}

The statistical results above proved the positive effect of SL on developing EFL functional writing skills for the study group, which could be attributed to the

\section{International Journal of Curriculum \& Technological Education}


diverse activities that addressed divergent learning styles and practiced by students throughout implementing SL (Kaye,2010; Nodoushan \& Pashapour, 2016; Stanton, Giles \& Cruz, 1999), in turn, such activities caused improvement in students' EFL functional writing skills. Additionally, SL provided an authentic and meaningful context of language learning and language usage (Elwell \& Bean, 2001; Kaye,2010; Perren, Grove, \& Thornton, 2013), which played a successful and working part in motivating students, causing their deep engagement (Crick ,2012), and consequently leading to their improved writing (Becket, Refaei, and Skutar, 2012; Franco, 2007; Miller, Berkey, Griffin, 2015; Nodoushan \& Pashapour, 2016; Ravitch, 2007; Stanton, Giles \& Cruz, 1999).

Results above showed that through SL, the overall EFL functional writing skills, namely, book review, report and letter writing were developed through implementing SL. Such results are in consistent with (Becket et al. 2012; Franco, 2007; Heuser, 1999; Marlow, 2007; Miller et al. 2015; Minor, 2001; Spack, 2006; Wurr, 2002, 2009) who assure that service-learning courses give non -native English language speakers genuine opportunities for improving their English language mastery in all skills. However, the previous studies (Becket et al. 2012; Franco, 2007; Heuser, 1999; Marlow, 2007; Miller et al. 2015; Minor, 2001; Spack, 2006; Wurr, 2002, 2009) were concerned with using SL in teaching and improving ESL for college students. Meanwhile, the present study used SL to explore its effectiveness in improving EFL functional writing skills for secondary students.

Obviously, the results of the present study showed that the progress in the functional writing skills happened at varied rates among the book review, report and letter. The largest development was in the book review, which could be attributed to the type of service students presented; the direct type that took place in the form of workshops the participants conducted, for teaching their peers how to write a book review. Through the workshops, the participants practiced one to one peer teaching that led to more learning engagement and then more understanding of the book review writing from the part of the participants, which led eventually to a better performance on the posttest. Such results coincide with (Halliday, 1975; Vygotsky 1978; Widdowson, 1978) who suggest that social interaction is essential for cognitive and language development.

Moreover, the comparison between the development of report writing and letter writing on the posttest showed that the development of report writing came in the second place and the development of letter writing was in the third place. Such results could be attributed to the fact that the participants used multi-resources, in the process of searching for information on water shortage in Egypt, in the second

\section{International Journal of Curriculum \& Technological Education} https://ijcte.journals.ekb.eg

Online ISSN: 2735-511X 
project. Such resources included doing research on the internet, plus, doing a field trip to the Soil Water and Environment Resources Institute (SWERI) in Giza, and attending a lecture there by Professor Fouad Ahmed, a specialist in agriculture and water resources in Egypt, on water shortage in Egypt. On the other hand, in the third project, which dealt with the disadvantages of cyber-bullying, students just relied on doing research on the internet. In other words, using the first-hand resource of information (the field trip to SWERI) in the second project played the role of an authentic resource of information shared by the outside school community (SWERI), and fostered the partnership between the outside school community and the participants, which led to creating a more meaningful context of learning, and more deep learning engagement. Consequently students' report writing (in the second project) outperformed their letter writing (in the third project) on the posttest. Such results are aligned with (Becket, Refaei, and Skutar, 2012; Bringle \& Hatcher, 1996; Eyler, 2002; Kaye, 2010), who believe that through taking part in service learning, partnerships are established among the community members, parents and other students as well as with people from organizations. They further emphasize that such relationships are reciprocal and mutually rewarding.

Additionally, the statistical results of the present study indicated that through SL, the book review writing skill was developed in general, which is compatible with (Becket et al. 2012; Franco, 2007; Heuser, 1999; Marlow, 2007; Miller et al. 2015; Minor, 2001; Spack, 2006; Wurr, 2002, 2009), who note that service-learning courses, give non -native English language speakers genuine opportunities for improving their English language mastery in all skills.

However, the results indicated that the different sub-skills of book review writing were developed at different rates. The largest development happened in style, content and organization sub- skills. Such development might be due to the reflection journals kept by the students and the workshops students conducted for teaching their school friends book review writing. It could be through such reflection journals and workshops, students' recognition of the style, organization and content of the book review were enhanced, and in turn, their writing was developed.

On the other hand, the least development was found in vocabulary and grammar sub-skills which coincide with (Spada, 2007), who believes that communicative language approaches like SL "give priority to fluency over accuracy and the emphasis is on the comprehension and production of messages, not the teaching or correction of language form." (p. 272). Moreover, such results coincide with (Miller et al. 2015; Richards \& Rodgers, 1986; Spada, 2007), who criticize the 
communicative language teaching for lacking explicit grammar and structure instruction.

Furthermore, the statistical results of the current study proved that through SL, the report writing skill was developed in general. Such results are aligned with (Becket et al. 2012; Franco, 2007; Heuser, 1999; Marlow, 2007; Miller et al. 2015; Minor, 2001; Spack, 2006; Wurr, 2002, 2009), who assure that service-learning courses, give non -native English language speakers genuine opportunities for improving their English language mastery in all skills.

Nevertheless, the findings showed that the different sub-skills of report writing were developed at different rates. The largest development happened in content and organization sub- skills. Such improvement might be due to the activities students practiced through SL, like doing research, doing a field trip to the Soil Water and Environment Resources Institute (SWERI) in Giza, and getting information on the scarcity of water in Egypt from the lecture given by Professor Fouad Ahmed, a specialist in agriculture and water resources in Egypt, creating a documentary on the problem of water scarcity in Egypt, and doing presentations to their school friends about the problem of water scarcity in Egypt.

Whereas, the least developed sub-skills in report writing were style, vocabulary and grammar. Such little development in style and vocabulary, in the course of the study, might be due to the type of the assigned report, which was a scientific one, and which required some scientific terms to be fully recognized and acquired by the students. In addition, the duration of the SL project might not be long enough to acquire such vocabulary and terms. Regarding the least development in grammar, in the course of the study, they are in consistent with (Spada, 2007), who believes that communicative language approaches like SL "give priority to fluency over accuracy and the emphasis is on the comprehension and production of messages, not the teaching or correction of language form." (p. 272). Additionally, such grammar results are in line with (Miller et al. 2015; Richards \& Rodgers, 1986; Spada, 2007), who criticize the communicative language teaching for lacking explicit grammar and structure instruction.

Finally, results showed that through applying SL, the letter writing skill was developed in general. Such results are in line with (Becket et al. 2012; Franco, 2007; Heuser, 1999; Marlow, 2007; Miller et al. 2015; Minor, 2001; Spack, 2006; Wurr, 2002, 2009), who assure that service-learning courses, give non -native English language speakers genuine opportunities for improving their English language mastery in all skills. Meanwhile, the results indicated that the different sub-skills of 
the letter writing were developed at different rates. The largest development occurred in style, content and organization and vocabulary sub- skills, which could be attributed to the different activities students engaged in, through implementing SL, such as doing research, acting sketches, conducting forums and designing posters to enhance awareness on cyber-bullying. On the other hand, the least developed sub-skills in letter writing were the grammar skills. Such results go along with (Spada, 2007), who notes that communicative language approaches like SL "give priority to fluency over accuracy and the emphasis is on the comprehension and production of messages, not the teaching or correction of language form." ( $p$. 272). Such grammar results are also aligned with (Miller et al. 2015; Richards \& Rodgers, 1986; Spada, 2007), who criticize the communicative language teaching for lacking explicit grammar and structure instruction.

\section{Conclusion \& Recommendations}

On the basis of the findings of this study, it was proved that using SL has a positive effect on developing EFL functional writing skills for the second secondary students. Such results could be attributed to the divergent learning styles addressed by SL, real-world and meaningful context of learning created through implementing it, consequently deep understanding and learning engagement by the participants, which all led to the improvement of students' EFL functional writing skills, namely; book review, report, and letter in terms of style, organization, content, vocabulary and mechanics.

In order to achieve successful learning experiences from SL, it is recommended that SL should begin with clearly established learning goals which identify both the academic content and tasks or competencies that students will be expected to perform upon the completion of the course. In addition, it is recommended that students should be involved in choosing their community placements, and deciding the ways in which they want to be involved. The advantage of allowing students to make these decisions is that such decisions are potentially, an important component for genuine experiential learning to take place. Moreover, SL should involve formative assessment to enhance students' learning throughout the service-learning project(s). Accordingly, reflection activities, before, during and after SL and activities like classroom discussions, presentations, and journal and paper assignments that support analysis of service experience in the context of the academic course and civic learning objectives, can guarantee such formative evaluation. Additionally, it is important for the instructors to share information about the educational requirements and the reciprocal and mutually rewarding outcomes 
of their course with their community partner(s) to get their solid support and encouragement.

\section{Suggestions for Further Studies}

The researcher suggests further studies on the following:

- Investigating the effectiveness of using service learning in developing the creative writing for the EFL secondary students.

- Using service learning as an interdisciplinary approach for teaching EFL.

- Using service learning for enhancing EFL learners' Language acquisition in listening, speaking and reading and their attitudes towards them.

- Service learning enhances EFL learners' $21^{\text {st }}$ century skills.

- Using service learning as a multisensory approach for developing EFL skills.

\section{References}

- Abdallah, M. (2014). Teaching and learning English functional writing: investigating Egyptian EFL student teachers' currently-needed functional writing skills. Research Paper Presented at the International Educational Conference: Colleges of Education \& Restructuring Education hosted and organized by Assiut University College of Education, Assiut, Egypt.

- Astin, A., Vogelgesang, L., Ikeda, E., \&Yee, J. (2000). How servicelearning affects students. Los Angeles: ULCA Higher Education Research Institute.

- Bahgat, R. (2011). The effectiveness of a suggested strategy based on mastery learning model in developing English functional writing skills for preparatory stage students (Master's thesis). Institute of Education, Cairo University, Cairo.

- Bates, T., (2014). Are universities teaching the skills needed in knowledge based economy? Retrieved from http: //www.tonybates.ca/2014/05/2/9 areuniversities-teaching-the-skills-needed-in-a-kowledge-based-economy/.

- Boss, J. A. (1994). The effect of community service work on the moral development of college ethics students. Journal of Moral Education, 23(2), 183-198.

- Brail, S. (2016). Quantifying the value of service-learning: a comparison of grade achievement between service-learning and non-service-learning 
students, International Journal of Teaching and Learning in Higher Education, 28(2), 148-157 http://www.isetl.org/ijtlhe/ ISSN 1812-9129

- Brandsford, J., Brown, A., \& Cocking, R. (2000). How people learn: brain, mind, experience, and school. Washington, DC: National Academy.

- Bringle. R., \& Hatcher, J. (1996). Implementing service learning in higher education, Journal of Higher Education, 67(2), Ohio State University Press

- The Common European Framework of Reference for Languages (CEF or CEFR). Retrieved from

- http://www.globallearningcircles.org/lcguide/p6.close/6.certificate.html

- Community Engagement | California State University, Northridge (CSUN). Retrieved on October 15,2017, from http://www.csun.edu/undergraduatestudies/community-engagement/continuum-service-and-communityengagement retrieved on 10/15/2017

- Crick, R. D. (2012). Deep engagement as a complex system: Identity, learning power and enquiry. In S. L. Christenson, A. L. Reschly, \& C. Wylie (Eds.), Handbook of research on student engagement (pp. 675-694). New York, NY: Springer-Verlag. https://doi.org/10.1007/978-14614-2018-7_32

- Dale, E. (1969). Audiovisual methods in teaching. New York, NY: Dryden Press.

- Daudelin, M. (1996). Learning from experience through reflection. Organizational Dynamics, 24(3), 36-48.

- Dewey, J. (1938). Experience and education. New York: Macmillan.

- Education for All 2015 National Review. Retrieved from: www.efa2015reviews@unesco.org

- Elsayed, A. (2012).Using different types of correction feedback to develop first secondary school EFL students' writing attitude and performance (Ph.D. dissertation).Department of Curricula and Instruction, Cairo University, Egypt.

- Elwell, M., \& Bean, M. (2001). The efficacy of service-learning for community college

- ESL students. Community College Review, 28(4), 47-59.

- Eyler, J., Giles, D., \& Schmiede, A. (1996). A practitioner's guide to reflection in service-learning. Nashville: Vanderbilt University.

- Eyler, J., \& Giles, D. (1999). Where's the learning in service-learning? San Francisco: Jossey-Bass.

- Felten, P., \& Clayton, P. (2011). Service learning. New Directions for Teaching and Learning, 128, 75-84. http://dx.doi.org/10.1002/t1.470 
- Franco, R. (2007). Using service-learning to build attainment pathways. In M. Baratian, D. K. Duffy, R. Franco, A. E. Hendricks, \& T. Renner (Eds.), Service-learning course design for community college (pp. 5-16).

Providence RI: Campus Compact.

- Giles, D., \& Eyler, J. (1994). The theoretical roots of service-learning in John Dewey: Toward a theory of service- learning, Michigan Journal of Community Service Learning, 1(1), 77-85.

- Graham, S., \& Perin, D. (2007). Writing next: Effective strategies to improve writing of adolescents in middle and high schools - a report to Carnegie Corporation of New York. Washington, DC: Alliance for Excellent Education.

- Halliday, M. (1975). Learning how to mean. London :Edward Arnold.

- Hartnett, C. (1997). A functional approach to composition offers an alternative. Composition Chronicle: Newsletter for Writing Teachers, 10(5), 5-8.

- Heuser, L. (1999). Service-learning as pedagogy to promote the content, cross-cultural,

- And language-learning of ESL students. TESL Canada Journal, 17, 54-71.

- Ibrahim, S. (2016). The effectiveness of a training program based on interactive multimedia in light of scaffolding in developing English language reading and writing skills among first year secondary students (Ph.D.dissertation). Curriculum and Instruction Department, Faculty of Education, Ain Sham University, Egypt.

- Kaye, C. (2010). The Complete Guide to Service Learning. USA: Free Spirit Publishing Inc.

- Katawy, M., \& Abou Jamous, A.(2015).The impact of using service learning in developing the concepts of citizenship among the tenth grade students in Jordan. Jamaa, 19(2), 141-176.

- Khodary, A. (2010). The effectiveness of a process writing program in developing some functional writing skills of student-teachers of English language (Master's thesis). Women's College, Ain Sham University, Egypt.

- Marlow, S. (2007). Creating authentic dialog: ESL students as recipients of service learning. Internet TESL Journal, 13(7). Retrieved from http://iteslj.org/Techniques/Marlow-ServiceLearning.html

- Miller, J., Berkey, B., \& Griffin, F. (2015). International students in American pathway programs: learning English and culture through service- 
learning, Journal of International Students, 5(4), 334-352.

http://jistudents.org/

- The National Curriculum Framework for English as a Foreign Language:

Grades 1-12 Egypt. (2012). Retrieved from

http://moe.gov.eg/ccimd/pdf/english_quality1.pdf

- Nodoushan, S., \& Pashapour, A. (2016). Critical pedagogy, rituals of distinction, and true professionalism. Journal of Educational Technology, 13(1), 29-43.

- Onchera, P., \& Manyasi, B. (2013). Functional writing skills for effective communication: The English language classroom in Kenya, Journal of Emerging Trends in Educational Research and Policy Studies (JETERAPS). 4(6), 842-847 @ Scholarlink Research Institute Journals, 2013 (ISSN: 21416990) jeteraps.scholarlinkresearch.org

- Plann, S. (2002). Latinos and literacy: An upper-division Spanish course with service learning. American Association of Teachers of Spanish and Portuguese, 85 (2), 330-338.

- Perren, J., Thornton, J., \& Grove, N. (2013). Three curricular innovations for service-learning in ESL programs. TESOL Journal, 4(3), 463-486.

- Ravitch, D. (2007). Experiential learning. In EdSpeak: A glossary of education terms, phrases, buzz- words, and jargon. Alexandria, VA: Association for Supervision and Curriculum Development.

- Riley, T. \& Douglas, S. (2016). The multicultural café: enhancing interaction for adult English language learners through service learning. TESL Canada Journal. 34(11). 25-50.

- Salem, A. (2013). The effect of writer's workshop approach to develop functional writing skills of primary stage pre-service English language teachers in Egypt (Master's thesis). Institute of Education, Cairo University, Egypt.

- Shaath, A. (2015). A suggested program based on self-regulated strategy development for developing English language functional writing skills at AlAzhar University - Gaza (Ph.D. dissertation). Faculty of women for Arts, Science \& Education, Ain Sham University, Egypt.

- Shadi, H. (2015). The effectiveness of web quest program in developing secondary school students' English reading and writing skills (Ph.D. dissertation). Department of Curricula and Instruction, Ain Sham University, Egypt.

- Spack, R. (2006). English lessons. TESOL Quarterly, 40(3), 595-604. 
- Stanton, T., Giles, Jr., \& Cruz, N. (Eds.). (1999). Service-learning: A movement's pioneers reflect on its origins, practice, and future. San Francisco: Jossey-Bass.

- Suleiman, E. ( 2015).The effect of a proposed task-based learning program on developing English reading and writing skills for the first year secondary school students (Ph.D. dissertation). Department of Curricula and Instruction, Cairo University, Egypt.

- Vygotesky, L. (1978). Mind in society. Harvard University Press.

- Widdowson, H. (1978). Teaching language as communication. Oxford: Oxford University Press.

- Wurr, A. (2002). Service-learning and student writing: An investigation of effects. In Furco, A. \& Billig, S. (Eds.), Service-learning through a multidisciplinary lens: Advances in service-learning research, 2, 103-121. Berkeley, CA: Information Age.

- Wurr, A. (2009). Composing cultural diversity and civic literacy: English language learners as service providers. Reflections: A journal on Writing, Service-Learning, and Community Literacy, 9(1), 162-190.

- World Bank Report. (2003). Lifelong learning in the global knowledge economy: challenges for developing countries. WBI Development studies, Washington, D.C.: World Bank.

- Zull, J. (2002). The art of changing the brain: Enriching the practice of teaching by exploring the biology of learning. Sterling: VA, Stylus Publications. 